\title{
POPULATION DYNAMICS OF Pseudomonas sp. ALONG A SPATIAL GRADIENT OF PHOSPHATE: AN EXPERIMENTAL APPROACH FOR SPATIAL ECOLOGY
}

\author{
CODEÇO, C. T. and GROVER, J. P. \\ Department of Biology, University of Texas at Arlington, POBox 19498, Arlington, TX, USA 79019 \\ Correspondence to: Cláudia T. Codeço, Programa de Computação Científica, Fundação Oswaldo Cruz, Av. Brasil, \\ 4365, Antiga Residência Oficial, CEP 21045-900, Rio de Janeiro, RJ, Brazil, \\ e-mail: codeco@malaria.procc.fiocruz.br \\ Received October 25, 1999 - Accepted January 3, 2000 - Distributed November 30, 2000
}

(With 4 figures)

\begin{abstract}
Many theoretical models have been proposed to study the effect of space on population dynamics and interactions, but most of them are difficult to translate into experimental setups due to their abstract nature. Here we defend the gradostat as a valuable experimental tool for testing such theories. The gradostat is a culture system with bi-directional flow that forms nutrient gradients at steady state. In this study, we use a 3-vessel gradostat with a phosphate gradient to study the effect of spatial heterogeneity on the spatial distribution of Pseudomonas sp., an heterotrophic aquatic bacterium. The observed distributions partially agree with theoretical predictions, obtained from a mathematical model.
\end{abstract}

Key words: gradostat, spatial ecology, experimental ecology, mathematical model.

\section{RESUMO}

Dinâmica Populacional de uma bactéria (Pseudomonas sp.) ao longo de gradiente espacial de fósforo: uma abordagem experimental para a ecologia do espaço

Vários modelos teóricos têm sido propostos para estudar o efeito do espaço em questões de dinâmica populacional e de interação entre espécies. Em geral, porém, os resultados teóricos obtidos são difíceis de serem validados devido à natureza abstrata da formulação destes modelos. Aqui, defendemos o uso do gradostato como modelo experimental para o teste destas teorias. O gradostato é um sistema de cultura de microorganismos com fluxo bidirecional que forma gradientes de nutrientes no equilíbrio. Neste estudo, usamos um gradostato de 3 vasos, com um gradiente de fósforo, para estudar o efeito da heterogeneidade espacial deste recurso na distribuição espacial de Pseudomonas sp., uma bactéria heterotrófica aquática. As distribuições espaciais obtidas corroboram parcialmente esperados teóricos de modelos matemáticos propostos na literatura.

Palavras-chave: gradostato, ecologia do espaço, ecologia experimental, modelo matemático.

\section{INTRODUCTION}

In the last decades, interest in space has increased substantially, since spatial heterogeneity may be a key for explaining patterns of population distribution, biodiversity, and stability of ecological communities (Tilman \& Kareiva, 1997). Many theoretical models have been proposed to deal with the effect of space on population dynamics and interactions, but most of them are difficult to translate into experimental setups, due to their abstract nature. Kareiva (1990) stressed out the existence of a large gap between theory and experimentation in spatial ecology and suggests stepping-stone models as the best candidates to close in these two disciplines. 
Here, we use the gradostat as an experimental model for testing ecological theories of population dynamics along spatial gradients of resources. The gradostat (Lovitt \& Wimpenny, 1979) is an array of interconnected culture vessels were medium and organisms flow in both directions (Fig. 1). Solutes that are fed only into one end of the array are distributed, at steady state, as a linear concentration gradient decreasing towards the other end. In the absence of organisms, a 3-vessel gradostat has concentrations in the first, second and third vessels equal to $3 / 4,1 / 2$, and $1 / 4$ of the supplied concentration, respectively.

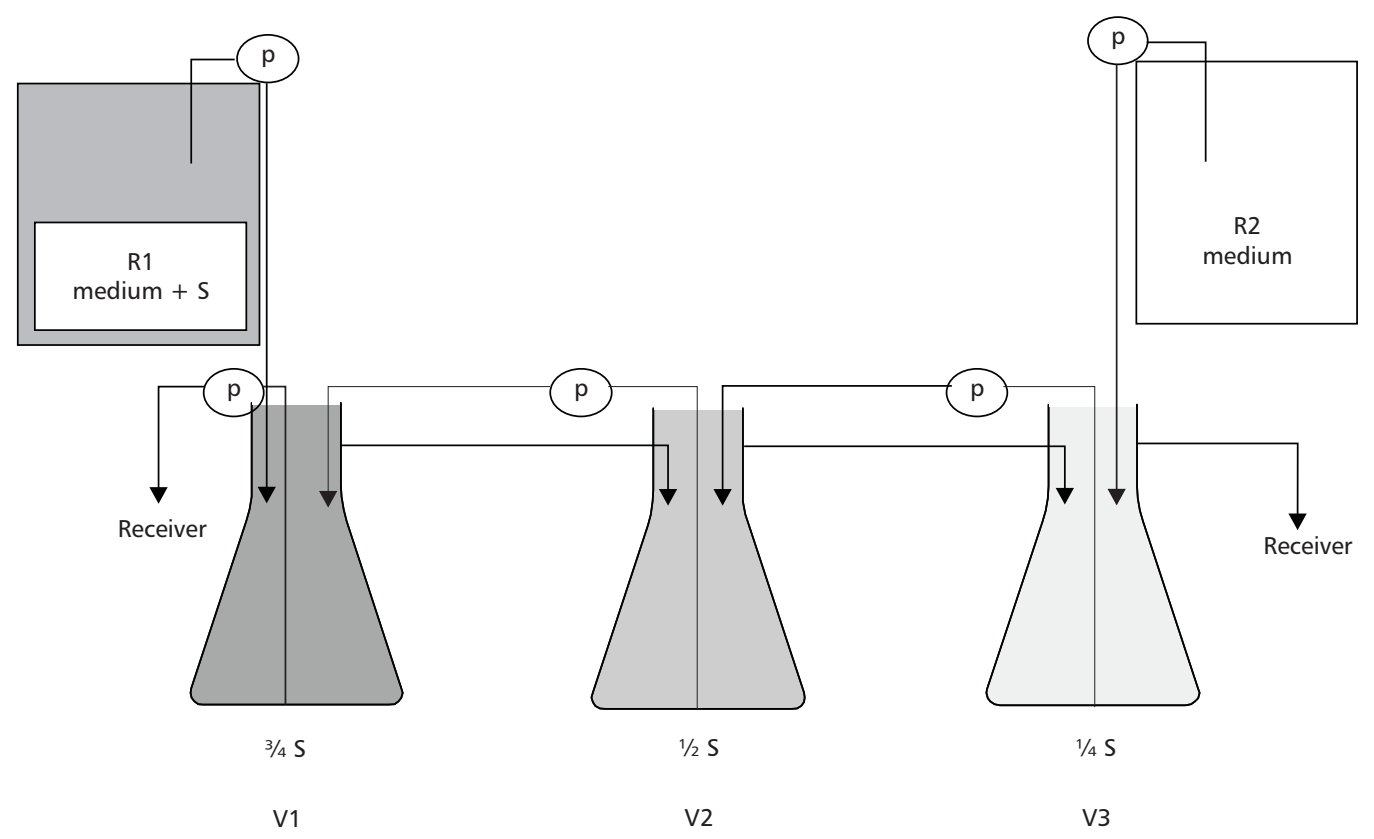

Fig. 1 - Schematic representation of a 3-vessel gradostat. Three culture vessels are arranged linearly (V1-V2-V3). End vessels receive sterile medium from reservoirs ( $\mathrm{R} 1$ and $\mathrm{R} 2$ ) and this medium is transferred in both directions from vessel to vessel and is removed from the end vessels. R1 contains sterile medium with phosphate while R2 contain the same medium without phosphate. "S" is the amount of phosphate present in R1. A peristaltic pump drives the flow from V3 to V1 while the opposite movement is driven by overflow. At steady state P is distributed through the vessels as a linear gradient.

Some rough analogies may be found between the gradostat and natural systems. By supplying seawater to one end and freshwater to the other end, a gradostat can be used to simulate an estuary. Flow in both directions can be regulated to represent tides. Cooper \& Copeland (1973) uses an experimental model very similar to the gradostat to study the effect of pollution on the structure of an estuarine planktonic community.

In the gradostat, steady-state population density in each vessel is a result of the balance between immigration, emigration, and reproduction. Theoretical conditions for growth and persistence along the gradostat spatial gradients have been studied by many authors (El-Owaidy \& El-Leithy, 1990;
Smith, 1991b; Tang, 1986; Jager et al., 1987; Smith, 1991a; Smith \& Tang, 1989; Smith, 1991a; Smith \& Waltman, 1991b; Zaghrout, 1992). This theory, briefly introduced in the appendix, formulates a set of differential equations that describe the dynamics of populations and limiting resources within each vessel of the gradostat.

One of the most interesting predictions of the gradostat theory is the large impact of flow rate on population distribution. At low flow rates, population distribution is expected to follow the concentration of the limiting nutrient, i.e., organisms should concentrate in the vessel receiving more P (V1, according to Fig. 1) and population density should correlate with resource concen- 
tration. As one increases the flow rate, however, population distribution should become uncorrelated with resource concentration. At high flow rates, vessels at the ends of the array become sinks for the population because dilution rate exceeds growth rate. Organisms would then concentrate in the middle vessel where dilution rate is lower, generating a triangular distribution.

The theory presented above was tested by recording the spatial distribution of a heterotrophic aquatic bacterium, Pseudomonas sp. in a 3-vessel gradostat with a gradient of $\mathrm{P}$, under various flow rates. The observed distributions were compared to those predicted by the mathematical model, calibrated for this organism (appendix).

\section{MATERIAL AND METHODS}

\section{Gradostat experiment}

A 3-vessel gradostat was assembled using $250 \mathrm{ml}$ Erlenmeyer flasks as culture vessels. Silicone stoppers with five holes sealed the tops. Teflon tubes fitted to the holes provided 2 input and 3 output ports. Culture volumes were $280 \mathrm{ml}$. Five liter bottles with sterile medium (reservoirs) were connected to the end vessels. WC medium (Guillard, 1973), enriched with $1 \mathrm{mM} \mathrm{C}$ (as glucose) was used. A gradient of phosphate was generated by supplying reservoir 1 with $2.2 \mu \mathrm{M}$ $\mathrm{P}$ (as $\mathrm{Na}_{2} \mathrm{HPO}_{4}$ ) and by not adding any phosphorus to reservoir 2. A multi-channel peristaltic pump drove flow from vessel 1 to 3 , while overflow controlled flow from 3 to 1 . All three culturevessels were bubbled with filtered air $(0.22 \mu \mathrm{m})$ and kept in a $25^{\circ} \mathrm{C}$ water bath. The whole system was sterilized by autoclaving for 1 hour. After cooling down, medium was pumped through vessels until the steady state distribution of the limiting nutrient was reached. Then, organisms from a pure laboratory culture of Pseudomonas sp., were inoculated. These bacteria were kept, for 5 to 7 days before each experiment, in liquid WC with glucose, at $25^{\circ} \mathrm{C}$, for acclimatization.

To minimize wall growth, experimental runs were limited to ca. 15 days and two runs are reported here. In the first run, cell densities were measured at flow rates 1.8 and 2.9 day $^{-1}$. In the second run, flow rates were set at 3.7 and 0.77 day $^{-1}$. The experiments were allowed to run at each flow rate until steady state conditions were achieved for at least three days, before changing to the next flow rate. Cell counts were performed every two days (Hobbie et al., 1977). Total phosphorus was measured in the last day (Strickland \& Parsons, 1972) to check for the presence of the chemical gradient.

\section{Estimation of model parameters}

Pseudomonas maximum growth rate $\left(\mu^{\max }\right)$ and half saturation constant $\left(\mathrm{K}_{\mathrm{p}}\right)$ were estimated according to method proposed by Kilham (1978). Pseudomonas, after growing until stationary phase in WC medium with no supply of phosphate, was delivered into $100 \mathrm{ml}$ batch cultures with glucoseenriched WC medium plus 0, 0.01, 0.05, 0.1, 0.5, 1 or $4 \mu \mathrm{MPO}_{4}$. Triplicates of each treatment (total of 21 flasks) were kept at $25^{\circ} \mathrm{C}$. Eight samples were taken from each culture, in intervals of 2 hours, starting at 8 hours from the inoculation. Growth rate $(\mu)$ was calculated for each experimental culture by fitting a regression line to the natural $\log$ of cell density against time. Growth function (Table 1) was fitted to these growth rates against initial P using nonlinear regression.

Cell Yield was estimated as the inverse of cell quota, the amount of P per cell (Kilham, 1978). Cells were initially grown in batch culture until stationary phase, and delivered into $280 \mathrm{ml}$ chemostats, receiving sterile WC medium (with $1 \mathrm{mM}$ $\mathrm{C}$ as glucose and $0.2 \mu \mathrm{M} \mathrm{PO}_{4}$ ), at various turnover rates. Cell counts were performed daily and when cultures reached steady state, soluble reactive phosphate (SRP) was analyzed (Strickland \& Parsons, 1972). In cultures with sufficient medium left in the reservoir, a new dilution rate was set, covering a range of 0.5 to 3.5 volumes/day. Cell yield was calculated for each flow rate as (total number of cells $) /\left(\mathrm{SRP}_{\text {reservoir }}-\mathrm{SRP}_{\text {culture }}\right)$.

\section{RESULTS AND DISCUSSION}

The Fig. 2 shows the spatial distribution of cells, observed at four flow rates $(f)$. At the lowest flow rate $\left(f=0.77\right.$ day $\left.^{-1}\right)$, density was maximum near the source of phosphate (V1) and decreased almost linearly towards V3. When flow was increased to 1.8 day $^{-1}$, the middle vessel became the place of highest density. This triangular pattern was maintained as flow was increased to 2.9 and 3.7 day $^{-1}$. The highest dilution rate used is close to the Pseudomonas maximum growth rate. 

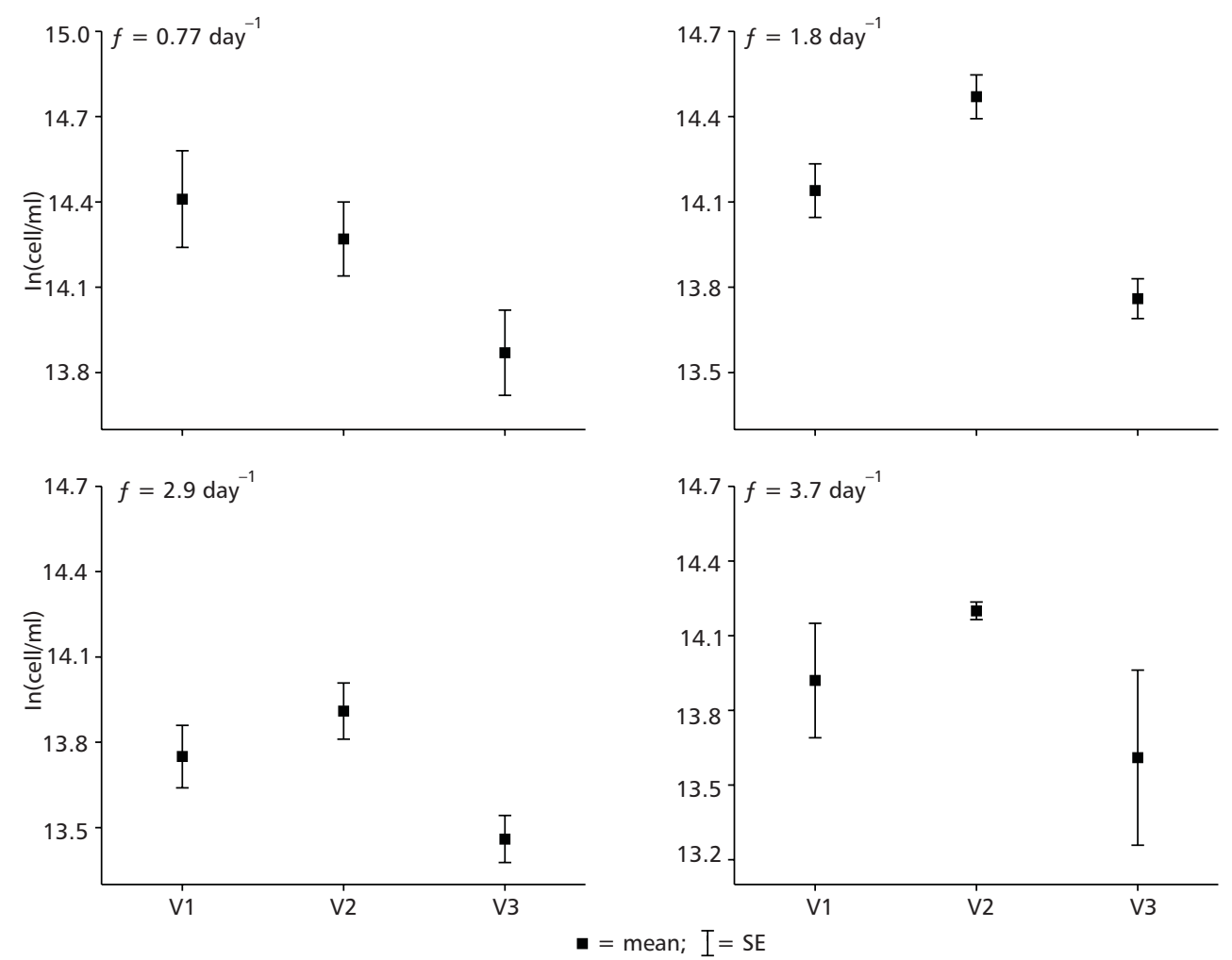

Fig. $2-$ Spatial distribution of cells (mean \pm SE) in the gradostat, at four dilution rates $\left(f=0.77,1.9,2.8\right.$ and 3.7 day $^{-1}$, $\mathrm{n}=4,7,7,5$, respectively).

The observed shift in the spatial distribution of Pseudomonas suggests that factors controlling population density may change as flow rate increases. At low flow rates, most nutrient uptake (and growth) takes place in the first vessel and densities in the other vessels result only from immigration. Competition is strong in V1, the source of organisms. The other vessels are sinks, and populations are maintained by dispersal. With increasing flow, organisms in V1 cannot consume as much resource, and more nutrients reach V2 and V3. The importance of V1 as source of organisms is reduced. Eventually, dispersal and not growth dictates the spatial pattern of species distribution. Vessels at the end of the gradostat only receive migrants from one contiguous vessel while middle vessels receive from two contiguous vessels. As immigration dominates over growth, cells will tend to concentrate in the middle vessel (center of migration), generating the triangular pattern observed. Similar shifts from growth-dependent to migration-dependent dynamics have been observed in streams. In these ecosystems, a shift from density dependent to density independent mechanisms of population control is postulated when flow rate is increased (Shiozawa, 1981).

Equations A1-A4 were parameterized for Pseudomonas, with values estimated from batch culture experiments (Table 1).

To choose an appropriate value for $\mathrm{Y}$ (cell yield) was tricky. Cell yield varied with growth rate (Fig. 3). This phenomenon is well described in the literature (Vadstein \& Olsen, 1989; Chen, 1974). In the gradostat, growth rate depends on the balance between immigration and emigration, and cannot be assessed a priori, although it is less than $2 f$ (Tang, 1986). Since equation A1 asks for a single value of $\mathrm{Y}$, we opted for an intermediary value, between the range of expected growth rates. Other values were also used in the analyses without qualitative changes on model predictions.

The parameterized model was numerically solved using the Runge-Kutta method of integration with variable step size (software MatLab). Simulations were carried out at different flow rates and the results are shown in Fig. 4. 


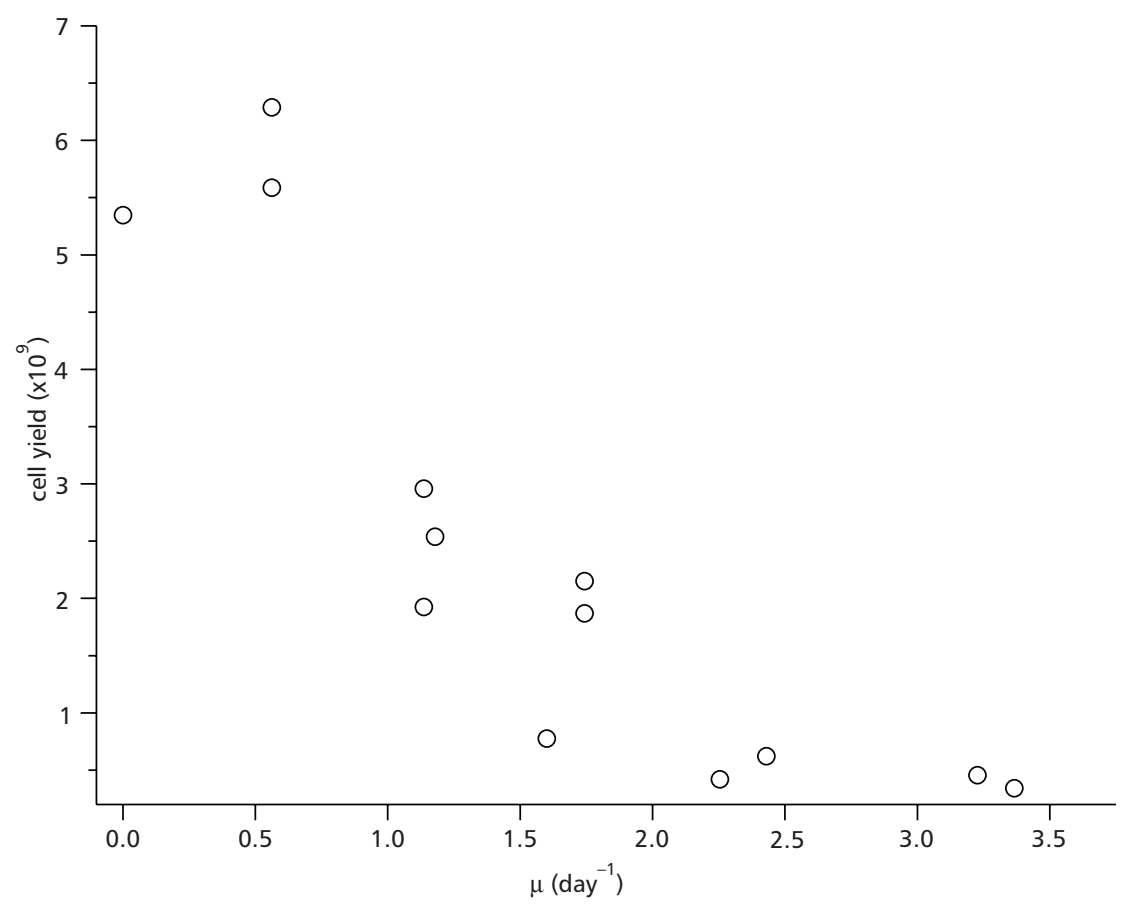

Fig. 3 - Dependence of cell yield (measured as the inverse of cell quota) on growth rate.

TABLE 1

Notation for the mathematical model and values used in simulations (values estimated from the experiments).

\begin{tabular}{|c|c|c|}
\hline \multicolumn{2}{|c|}{ State variables: } & \multirow[t]{2}{*}{ Values } \\
\hline $\mathrm{R}_{\mathrm{i}}$ & Resource concentration in vessel $\mathrm{i}(\mu \mathrm{M})$ & \\
\hline $\mathrm{N}_{\mathrm{i}}$ & Population density in vessel i (cells/liter) & \\
\hline \multicolumn{3}{|c|}{ Operational parameters: } \\
\hline$S$ & Concentration of $\mathrm{R}$ in Reservoir $1(\mu \mathrm{M})$ & $2.2 \mu \mathrm{MP}$ \\
\hline f & $\begin{array}{l}\text { Rate of transport between contiguous vessels, between reservoirs and } \\
\text { vessels and, between vessels and receivers }\left(\text { day }^{-1}\right)\end{array}$ & $0.77,1.8,2.9$, or 3.7 \\
\hline $\mathrm{n}$ & Total number of vessels & 3 vessels \\
\hline \multicolumn{3}{|c|}{ Biological parameters and functions } \\
\hline$\mu$ & Growth rate $\left(\right.$ day $\left.^{-1}\right)$ & \\
\hline$\mu^{\max }$ & Maximum growth rate $\left(\mathrm{day}^{-1}\right)$ & 3.67 day $^{-1}$ \\
\hline $\mathrm{K}$ & Half-saturation constant $(\mu \mathrm{M})$ & $0.012 \mu \mathrm{M}$ \\
\hline $\mathrm{Y}$ & Yield of cells per unit of resource (cells $/ \mu \mathrm{mol})$ & $1 \times 10^{9} \mathrm{cells} / \mu \mathrm{mol} \mathrm{P}$ \\
\hline
\end{tabular}

The expected shift in cell distribution is obtained. The model, however, predicts that the shift to a migration-dependent pattern should occur at a much higher flow rate than that observed in the experiments
(Fig. 2). One possible explanation for this disagreement is the assumption of constant cell yield. In the gradostat, organisms experience different growth rates in each vessel, and cell yield should vary too. 


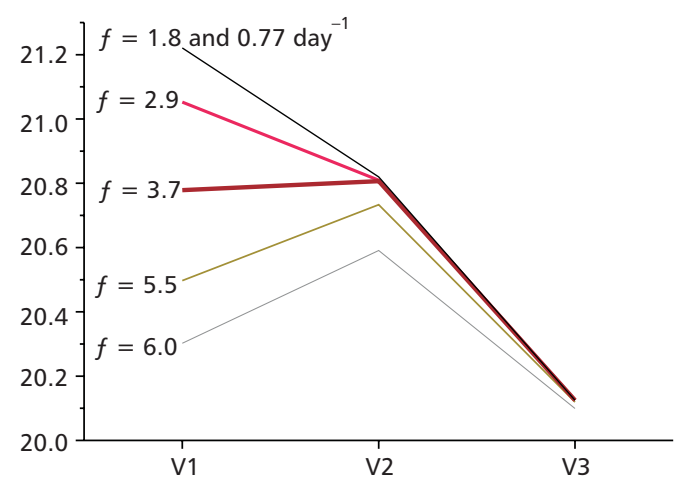

Fig. 4 - Expected effect of flow rate on the spatial distribution of cells. Simulation performed using equations A1-A4 with parameters listed in Table 1.

If this is the case, a more complex model that considers a variable Y, such as a Droop model (Droop, 1974; Grover, 1991), could solve the problem.

In the Droop model, $\mathrm{Y}$ is a dynamic variable that varies inversely with growth rate. A potential drawback of this approach, however, is that each gradostat vessel is composed by a mixed population of resident organisms and migrants from different origins. Each one of these groups has its own nutrient content as they come from different growth conditions. If a set of equations is used to model the population dynamics and yield dynamics of each one of these groups in each vessel of the gradostat, it would increase enormously the complexity of the model!

Our results suggest that, in aquatic environments subjected to bi-direction water flow, increase in circulation alone should shift population distribution from growth dependent to migration dependent. As a result, peak of abundance should shift from nutrient-rich habitats to regions away from the borders. In estuaries, the importance of water circulation on the spatial distribution of planktonic populations has been long recognized (Ketchum, 1954; Pace et al., 1992). This effect, however, is dependent on the relative scales of population growth and water turnover (Ketchum, 1954). Bacteria have generation times of the order of hours, phytoplankton of a few days, and zooplankton of a few days to months. Water turnover in estuaries may be too fast to cause bacterial distribution to be migration dependent. Thus, if other factors like predation and differential mortality are not considered, spatial distribution of bacteria should follow the distribution of the most limiting resource. Zooplankton, on the other hand, should be affected by the circulation dynamics of estuaries (flow dependent distribution). Pace et al. (1992) detected flow dependent sourcesink patterns on the distribution of Bosmina along six stations on the Hudson River estuary, with a $30 \mathrm{x}$ higher abundance in station 1 (up river) and a linear decrease seawards.

There is an urgent need for experiments in spatial ecology (Kareiva, 1990). The advantages of using the gradostat for this task include the existence of analytical theory and similarities with chemostats, which can be used as "null models" for the effect of spatial heterogeneity. Many applications have been suggested for the gradostat, from physiological to ecological to genetic studies. There is an open field waiting to be pursued.

\section{APPENDIX}

The gradostat has a well developed mathematical theory, with an approach similar to that of chemostat theory (El-Owaidy \& El-Leithy, 1990; Lovitt \& Wimpenny, 1981; Smith, 1991b; Tang, 1986). For each vessel i of the gradostat, a set of two differential equations describe the dynamics of a population $(\mathrm{N})$ and a limiting nutrient $(\mathrm{R})$ (see Table 1 for notation).

$\frac{d N_{i}}{d t}=f\left(N_{i-1}+N_{i+1}\right)-2 f N_{i}+\mu\left(R_{i}\right) N_{i}$ 


$$
\begin{gathered}
\frac{d R_{i}}{d t}=f\left(R_{i-1}+R_{i+1}\right)-2 f R_{i}-1 / Y \mu\left(R_{i}\right) N_{i} \\
\quad \text { for } \mathrm{i}=1 \text { to } \mathrm{n} \\
R_{0}=S, \quad R_{n+1}=N_{0}=N_{n+1}=0
\end{gathered}
$$

Equation A1 describes the dynamics of population $\mathrm{N}$ in vessel $\mathrm{i}$. The first term indicates that population density increases as migrants come in from its left $\left(\mathrm{N}_{\mathrm{i}-1}\right)$ and right $\left(\mathrm{N}_{\mathrm{i}+1}\right)$ vessels. The second term shows that organisms are lost to each one of the two neighbor vessels at a rate $f N_{i}$. The last term indicates population growth due to reproduction. Growth rate dependence on the local resource concentration is conventionally modeled by a Monod function (Monod, 1950):

$$
\mu\left(R_{i}\right)=\mu^{\max } \frac{R_{i}}{K+R_{i}}
$$

Equation A2 models the dynamics of the limiting resource (in our case, phosphorus). The amount of resource in each vessel increases with inflow from neighbor vessels (first term), and decreases by outflow (second term) and consumption (third term). The parameter Y (cell yield) indicates how much resource is removed when a cell is formed. In the absence of organisms $(\mathrm{N}=0)$, $\mathrm{R}$ distributes itself along the vessels as a linear gradient with concentration:

$$
R_{i}=S\left(1-\frac{i}{n+1}\right)
$$

The set of equations (A3) defines the boundary conditions applying to vessels 1 and $n$ : vessel 1 receives $C$ from its reservoir but not $P$, while vessel $n$ receives $\mathrm{P}$ but not $\mathrm{C}$. Neither end vessel receives organisms from the reservoirs.

The model presented above assumes no physiological death, instantaneous conversion of consumed resources into growth (no internal storage) and constant yield (Grover, 1997). To parameterize it, one only needs to estimate, for each population, the Monod parameters (maximum growth rate and half saturation constant) and cell yields.

Acknowledgments - This research was funded by the National Science Foundation, Grant \# DEB 9418096.

\section{REFERENCES}

CHEN, M., 1974, Kinetics of phosphorus absorption by Corynebacterium bovis. Microb. Ecol., 1: 164-175.

COOPER, D. C. \& COPELAND, B. J., 1973, Responses of Continuous-series estuarine microsystems to point-source input variations. Ecol. Monogr., 43: 213-236.

DROOP, M. R., 1974, The nutrient status of algal cells in continuous culture. J. Mar. Biol. Assoc. U.K., 54: 825-855.

EL-OWAIDY, H. \& EL-LEITHY, O. A., 1990, Theoretical studies on extinction in the gradostat. Math. Biosc., 101: $1-26$.

GROVER, J. P., 1991, Dynamics of competition among microalgae in variable environments: Experimental tests of alternative models. Oikos, 62: 231-234.

GROVER, J. P., 1997, Resource Competition. Chapman \& Hall, London, 342p.

GUILLARD, R. R. L., 1973, Methods for microflagellates and nanoplankton. In: J. R. Stein (ed.), Phycological Methods, Cambridge University Press, New York, pp. 69-85.

HOBBIE, J. E., DALEY, R. J. \& JASPER, S., 1977, Use of Nuclepore filters for counting bacteria by fluorescence microscopy. Arch. Microbiol., 33: 1225-1228.

JAGER, W., SO, J. W. H., TANG, B. \& WALTMAN, P., 1987, Competition in the gradostat. J. Math. Biol., 25: 23-42.

KAREIVA, P., 1990, Population dynamics in spatially complex environments: Theory and data. Phil. Trans. R. Soc. London B, 330: 175-190.

KETCHUM, B. H., 1954, Relationship between circulation and planktonic populations in estuaries. Ecology, 35: 191-200.

KILHAM, S. S., 1978, Nutrient kinetics of freshwater planktonic algae using batch and semicontinuous methods. Mitt. Internat. Verein. Limnol., 21: 147-157.

LOVITT, R. W. \& WIMPENNY, J. W. T., 1979, The gradostat: a tool for investigating microbial growth and interactions in solute gradients. Soc. Gen. Microbiol. Quart., 6: 8.

LOVITT, R. W. \& WIMPENNY, J. W. T., 1981, The gradostat: a bidirectional compound chemostat and its application in microbiological research. J. Gen. Microbiol., 127: 261268

MONOD, J., 1950, La technique de culture continue, théorie et applications. Annales d'Institute Pasteur, 79: 390-410.

PACE, M. L., FINDLAY, S. E. G. \& LINTS, D., 1992, Zooplankton in advective environments: The Hudson river community and a comparative analysis. Can. J. Fish. Aq. Sci., 49: 1060-1069.

SHIOZAWA, D. K., 1981, Density independence versus density dependence in streams. In: J. R. Barnes \& G. W. Minshall (eds.), Stream Ecology. Application and Testing of General Ecological Theory, Plenum Press, pp. 55-77. 
SMITH, H. L., 1991a, Competition in a modified gradostat. In: O. Orino, D. E. Axelrod \& M. Kimmel (eds.), Mathematical Population Dynamics, Malcel Dekker Inc, pp. 233-243.

SMITH, H. L., 1991b, Equilibrium distribution of species among vessels of a gradostat. J. Math. Biol., 30: 31-48.

SMITH, H. L. \& TANG, B., 1989, Competition in the gradostat: the role of the communication rate. J. Math. Biol., 27: 139-165.

SMITH, H. L., TANG, B. \& WALTMAN, P., 1991a, Competition in a n-vessel gradostat. SIAM J. Appl. Math., 51: 1451-1471.

SMITH, H. L. \& WALTMAN, P., 1991b, The gradostat: model of competition along a nutrient gradient. Microb. Ecol., 22: 207-226.

STRICKLAND, J. D. \& PARSONS, T., 1972, A Practical Manual of Seawater Analysis. Fishery Research Board of Canada, Ottawa.
TANG, B., 1986, Mathematical investigations of growth of microorganisms in the gradostat. J. Math. Biol., 23: 319339 .

TILMAN, D. \& KAREIVA, P. (eds.), 1997, Spatial Ecology: The role of space in population dynamics and interspecific interactions. Princeton University Press, Princeton.

VADSTEIN, O. \& OLSEN, Y., 1989, Chemical composition and phosphate uptake kinetics of limnetic bacterial communities cultured in chemostats under phosphorus limitation. Limnol. Oceanogr., 34: 939-946.

ZAGHROUT, A. A. F., 1992, Asymptotic behavior of solutions of competition in gradostat with two limiting complementary substrates. Appl. Math. Comp., 49: 19-37. 